\title{
Excessive daytime sleepiness among rural residents in Saskatchewan
}

\author{
John A Gjevre $\mathrm{MD}^{1}$, Punam Pahwa $\mathrm{PhD}^{2,3 *}$, Chandima P Karunanayake $\mathrm{PhD}^{2}$, Louise Hagel $\mathrm{MSc}^{2}$, \\ Donna C Rennie PhD², Josh Lawson $\mathrm{PhD}^{2}$, Roland Dyck MD${ }^{4}$, James A Dosman $\mathrm{MD}^{2 *}$; \\ and the Saskatchewan Rural Health Study Team**
}

\begin{abstract}
JA Gjevre, P Pahwa, CP Karunanayake, et al; and the Saskatchewan Rural Health Study Team. Excessive daytime sleepiness among rural residents in Saskatchewan. Can Respir J 2014;21(4):227233.

BACKGROUND: Obstructive sleep apnea (OSA) is a common diagnosis in clinical practice. Excessive daytime sleepiness may be a warning for possible OSA.

OBJECTIVES: To assess the prevalence of excessive daytime sleepiness as measured by the Epworth Sleepiness Scale (ESS) in a rural community population; potential risk factors for OSA were also assessed.

METHODS: In 2010, a baseline respiratory health questionnaire within the Saskatchewan Rural Health Study was mailed to 11,982 households in Saskatchewan. A total of 7597 adults within the 4624 (42\%) respondent households completed the ESS questionnaire. Participants were categorized according to normal or high $(>10)$ ESS scores. Data obtained included respiratory symptoms, doctor-diagnosed sleep apnea, snoring, hypertension, smoking and demographics. Body mass index was calculated. Multivariable logistic regression analysis examined associations between high ESS scores and possible risk factors. Generalized estimating equations accounted for the two-tiered sampling procedure of the study design.

RESULTS: The mean age of respondents was 55.0 years and $49.2 \%$ were male. The prevalence of ESS>10 and 'doctor diagnosed' OSA were 15.9\% and $6.0 \%$, respectively. Approximately $23 \%$ of respondents reported loud snoring and $30 \%$ had a body mass index $>30 \mathrm{~kg} / \mathrm{m}^{2}$. Of those with 'doctordiagnosed' OSA, 37.7\% reported ESS $>10(\mathrm{P}<0.0001)$ and $47.7 \%$ reported loud snoring $(\mathrm{P}<0.0001)$. Risk of having an ESS $>10$ score increased with age, male sex, obesity, lower socioeconomic status, marriage, loud snoring and doctor-diagnosed sinus trouble.

CONCLUSIONS: High levels of excessive daytime sleepiness in this particular rural population are common and men $>55$ years of age are at highest risk. Examination of reasons for residual sleepiness and snoring in persons with and without sleep apnea is warranted.
\end{abstract}

Key Words: Epworth Sleepiness Scale; Farm; Nonfarm; Obesity; Rural; Sleep apnea; Snoring; Socioeconomic

$\mathrm{P}$ oor sleep and excessive daytime sleepiness are common complaints, and patients frequently present to their health care providers with these concerns. Excessive daytime sleepiness has been noted to have a prevalence of $5 \%$ to $23 \%$ in the general population (1-10). While daytime sleepiness can be attributed to various underlying causes, it may be a warning sign of potential sleep-disordered breathing. There is increasing recognition that obstructive sleep apnea (OSA) is a major public health issue in the North American general population (11). Furthermore, sleep disorders are very common in general practice but symptoms are often under-recognized or under-reported (12). OSA has been acknowledged as a contributor to the development of significant comorbidities, as well as being associated with an increased rate of industrial and motor vehicle accidents $(13,14)$.

\section{Une somnolence diurne excessive chez des habitants des régions rurales de la Saskatchewan}

HISTORIQUE : L'apnée obstructive du sommeil (AOS) est un diagnostic courant en pratique clinique. La somnolence diurne excessive peut être évocatrice d'une AOS.

OBJECTIFS : Évaluer la prévalence de somnolence diurne excessive, mesurée selon l'échelle de somnolence d'Epworth (ÉSE), au sein de la population d'une communauté rurale. Évaluer également les facteurs de risque potentiels d'AOS.

MÉTHODOLOGIE : En 2010, dans le cadre de la Saskatchewan Rural Health Study, les chercheurs ont posté un questionnaire de base sur la santé respiratoire à 11982 ménages de la Saskatchewan. Au total, 7597 adultes au sein des 4624 (42\%) ménages des répondants ont rempli le questionnaire d'ÉSE. Les participants ont été classés selon des seuils d'ÉSE normaux ou élevés (plus de 10). Les données obtenues incluaient des symptômes respiratoires, l'apnée du sommeil diagnostiquée par le médecin, les ronflements, l'hypertension, le tabagisme et les données démographiques. Les chercheurs ont calculé l'indice de masse corporelle. Au moyen de l'analyse de régression logistique multivariée, ils ont examiné les associations entre des seuils d'ÉSE élevés et des facteurs de risque possibles. Les équations d'estimation généralisées tenaient compte du protocole d'intervention à deux niveaux utilisée dans la méthodologie de l'étude.

RÉSULTATS : Les répondants avaient un âge moyen de 55,0 ans, et 49,2 \% étaient de sexe masculin. La prévalence d'ÉSE supérieure à 10 et l'AOS diagnostiquée par le médecin s'élevaient à $15,9 \%$ et 6,0 \%, respectivement. Environ $23 \%$ des répondants déclaraient des ronflements bruyants et $30 \%$ avaient un indice de masse corporelle supérieur à $30 \mathrm{~kg} / \mathrm{m}^{2}$. Chez ceux ayant une AOS diagnostiquée par le médecin, 37,7 \% ont déclaré une ÉSE supérieure à $10(\mathrm{P}<0,0001)$ et $47,7 \%$, des ronflements bruyants $(\mathrm{P}<0,0001)$. Le risque d'ÉSE supérieure à 10 augmentait en fonction de l'âge, du sexe masculin, de l'obésité, de la situation socioéconomique, du mariage, des ronflements bruyants et des troubles sinusaux diagnostiqués par le médecin.

CONCLUSIONS : Des taux élevés de somnolence diurne excessive sont courants au sein de cette population rurale, et les hommes de plus de 55 ans y sont les plus vulnérables. L'examen des raisons de la somnolence résiduelle et des ronflements s'impose chez les personnes présentant une apnée du sommeil.

Various factors, such as age $(5,7,15,16)$, sex $(6,7,17,18)$, marital status $(19,20)$, smoking $(21,22)$, obesity $(23,24)$, socioeconomic status $(6,18,25)$ and medical history $(23,26,27)$, have been associated with daytime sleepiness or sleep apnea. However, there are limited data assessing sleep apnea prevalence or reviewing predictors for, and prevalence of, excessive daytime sleepiness in rural or remote populations. Saskatchewan is a large $\left(651,036 \mathrm{~km}^{2}\right)$, sparsely populated (population 1,072,082) province with a strong agricultural focus located in Western Canada. Of the provincial population, approximately $35 \%$ reside outside the two major urban centres in smaller communities and rural farmstead/remote settings. Of particular relevance in an agricultural and rural population, OSA indicators have been recently reported to be associated with increased injuries in farmers $(28,29)$.

*Co-principal investigators; **Saskatchewan Rural Health Study Team members are listed in the Appendix

${ }^{1}$ Division of Respirology, Critical Care and Sleep Medicine; ${ }^{2}$ Canadian Centre for Health and Safety in Agriculture; ${ }^{3}$ Department of Community Health and Epidemiology; ${ }^{4}$ Department of Medicine, College of Medicine; University of Saskatchewan, Saskatoon

Correspondence: Dr John A Gjevre, Division of Respirology, Critical Care and Sleep Medicine, University of Saskatchewan, 103 Hospital Drive, Saskatoon, Saskatchewan S7N OW8. Telephone 306-844-1009, fax 306-844-1532, e-mail john.gjevre@usask.ca 


\section{BOX 1}

Epworth Sleepiness Scale

How likely are you to doze off or fall asleep in the following situations, in contrast to feeling just tired? This refers to your usual way of life in recent times. Even if you haven't done some of these things recently try to work out how they would have affected you.

$0=$ would never doze

1 = slight chance of dozing

2 = moderate chance of dozing

$3=$ high chance of dozing

\section{Situation:}

Chance

of dozing

Sitting and reading

Watching TV

Sitting, inactive in a public place

As a passenger of a car for an hour without a break

Lying down to rest in the afternoon when circumstances permit

Sitting and talking to someone

Sitting quietly after a lunch without alcohol

In a car, while stopped for a few minutes in traffic

Total score

\section{Copyright () M.W.Johns 1990-1997}

The Epworth Sleepiness Scale (ESS) is a self-administered questionnaire that has been used to measure daytime sleepiness (30-32). The ESS has been widely used by researchers, clinicians and sleep specialists as a tool to identify and assess sleep apnea (33-35). The validity and reliability of the ESS has been evaluated (33,36-39). In an earlier pilot project, we studied the prevalence of a high ESS score in 283 rural residents $(40)$. The objective of the present study was to broaden the evaluation of excessive daytime sleepiness prevalence and determinants in the much larger rural population participating in the Saskatchewan Rural Health Study (SRHS) (41).

\section{METHODS}

Baseline survey design

The SRHS was designed as a prospective cohort study conducted in two phases: baseline and follow-up. Details of study design for the baseline survey have been previously reported (41). Briefly, 39 rural municipalities (RMs) of the 298 RMs in Saskatchewan and 16 of the 145 towns (generally having a population of 500 to 5000) in Saskatchewan were selected to participate in the study. These RMs and towns were selected at random from four quadrants of the province (southeast, southwest, northeast and northwest). The local councils for most of these 32 (89\%) of 36 RMs and 15 (94\%) of 16 towns agreed to participate on behalf of their residents and supplied mailing addresses. The method of Dillman $(42,43)$ was used to recruit study participants. The study population comprised 8261 individuals (men and women $\geq 18$ years of age) living in 32 RMs and 15 towns in the study area within 4624 households. Information regarding the variables described below was collected by self-administered, mailed questionnaires based on the Population Health Framework (44,45).

\section{ESS questionnaire}

The degree of sleepiness was assessed using the ESS (Box 1). The ESS score ranges from 0 to 24 . A score of 11 to 24 is considered to be abnormal and indicative of excessive daytime sleepiness (30). The primary outcome of interest was a binary variable of ESS score $>10$.

\section{SRHS survey questions}

Smoking status: Three types of smoking history were assessed, including current smoker (smoking in the past year) or ex-smoker (no current smoking and a history of smoking at least 20 packs), or nonsmoker (all others).
Body mass index: Body mass index (BMI) was calculated as weight $(\mathrm{kg}) /$ height $(\mathrm{m})^{2}$. BMI was based on self-reported information on height and weight. Overweight and obese were defined as $25 \mathrm{~kg} / \mathrm{m}^{2}$ to $30 \mathrm{~kg} / \mathrm{m}^{2}$, and $>30 \mathrm{~kg} / \mathrm{m}^{2}$, respectively.

Marital status: Marital status was categorized into two groups: married, common law or living together; and widowed, divorced, separated or single.

Alcohol: Alcohol consumption was captured using responses to the question "In the past 12 months have you had 5 or more drinks on one occasion?", and categorized as yes or no.

Self-reported physician-diagnosed medical history: Sinus trouble, heart disease, heart attack, hardening of the arteries, high blood pressure, tuberculosis, stroke, attack of bronchitis, diabetes, chronic bronchitis, emphysema, chronic obstructive pulmonary disease, asthma and shortness of breath.

Snoring: Data were collected using the questions "Do you snore?" and "If you snore, is your snoring: slightly louder than breathing?; as loud as talking?; louder than talking?; very loud - can be heard in adjacent rooms?". These questions were simplified into a new variable, loud snoring, by combining the above questions into two categories: no or slightly, and loud or very loud.

Residence: Designation of residence as farm or nonfarm (including town and self-described acreage) rural dwelling was based on the question 'Where is your home located?' (farm, town, acreage). Town and acreage were combined to create a nonfarm category.

Socioeconomic status: Socioeconomic status was assessed using household income adequacy, which was a derived variable with four categories based on various combinations of total household income and the number of people living in the household according the Statistics Canada definition (46), and a question concerning how much money was left over at the end of the month with the three categories: some money; just enough money; and not enough money.

Education: Highest educational attainment was categorized into four groups: less than high school; completed high school; completed university; and completed other postsecondary education.

\section{Statistical analysis}

Statistical analysis was completed using SAS version 9.03 (SAS Institute, USA). Logistic regression models were used to predict the relationship between a binary ESS $>10$ (yes or no) and a set of explanatory variables. A multilevel logistic regression modelling approach, including a generalized estimating equation, with individuals (first level) nested within households (second level), was used to evaluate the effects of covariates of interest. This accounts for the within-subject dependencies that occur in the analysis due to multiple individuals from one household. A series of multilevel models were fitted to determine whether potential risk factors, confounders and interactive effects contribute significantly to the prevalence of ESS score $>10$. Based on bivariable analysis, variables with $\mathrm{P}<0.20$ became candidates for a multivariable model. All variables that were statistically significant (ie, $\mathrm{P}<0.05$ ) as well as important factors (location of residence), were retained in the final multivariable model. A parsimonious model was selected based on the QIC (Quasi-likelihood under the Independence model Criteria) goodness-of-fit statistic $(48,49)$. The strength of associations is presented as ORs and associated 95\% CIs.

\section{RESULTS}

Of 11,982 households that were mailed questionnaires, 4624 (42\%) returned completed questionnaires, with 7597 individual adults 18 to 95 years of age responding to the sleep and ESS questions. The mean $( \pm$ SE) age was $55.0 \pm 0.17$ years, $49.2 \%$ were male and approximately $70 \%$ of the respondents reported snoring. Of those indicating snoring, $23.3 \%$ reported loud or very loud snoring, and $30 \%$ of those who snored had a BMI $>30 \mathrm{~kg} / \mathrm{m}^{2}$. Current smoking was relatively uncommon (12.0\% smokers, $35.6 \%$ ex-smokers and $52.4 \%$ never smokers). The majority of participants were Caucasian (96\%). The remaining $4 \%$ consisted of First Nation/Métis and other ethnic groups. 
TABLE 1

Univariate association between demographics, socioeconomic and medical history and Epworth Sleepiness Scale score

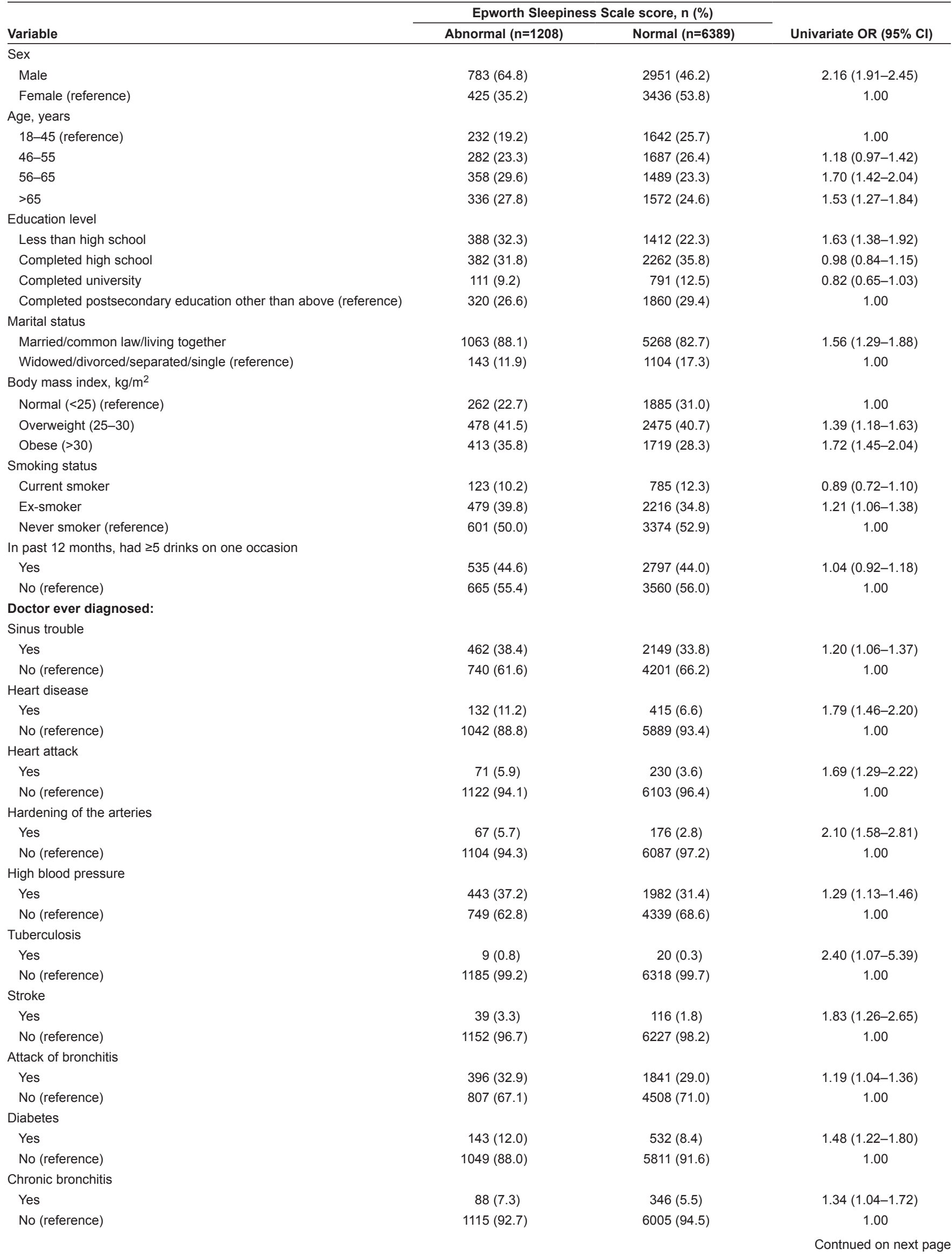


TABLE 1 - CONTINUED

Univariate association between demographics, socioeconomic and medical history and Epworth Sleepiness Scale score

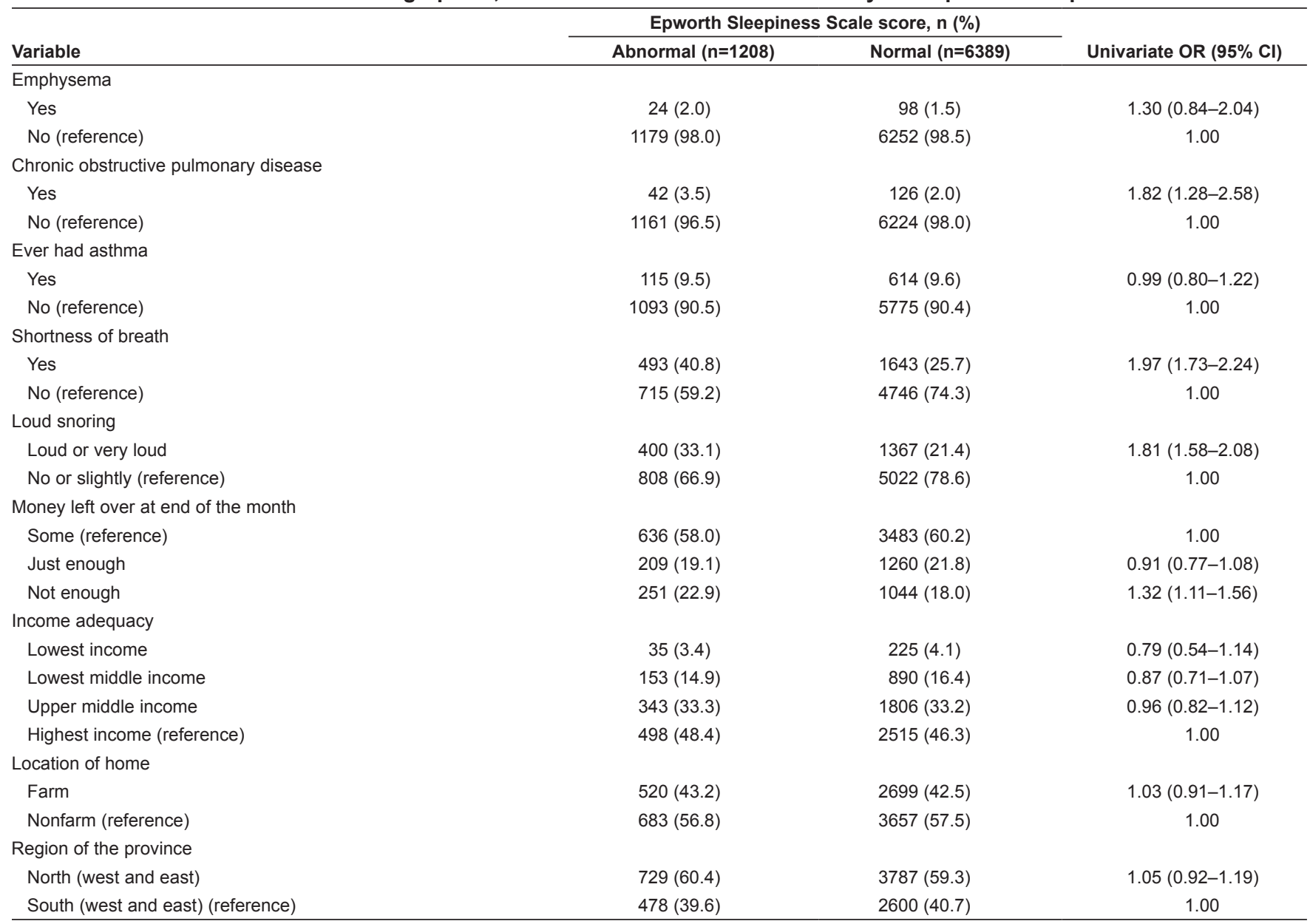

There were $6389(84.1 \%)$ participants with ESS scores $\leq 10$ and 1208 (15.9\%) with ESS score $>10$. Overall, the mean ESS score was significantly higher in men (mean $[ \pm S E] 7.31 \pm 0.07)$ than in women $(5.73 \pm 0.06)(\mathrm{P}<0.001)$. Among individuals with an elevated ESS score (ie, $>10)$, the mean ESS score was higher in men $(13.77 \pm 0.10)$ than women $(13.12 \pm 0.11)$, and the prevalence for men $(21 \%)$ was also higher than that observed in women $(11 \%)(\mathrm{P}<0.001)$. The overall prevalence of excessive sleepiness and self-reported 'doctordiagnosed' sleep apnea were $15.9 \%$ (95\% CI 15.1 to 16.7 ) and $6.0 \%$ (95\% CI 5.5 to 6.6), respectively. Of those with 'doctor-diagnosed' sleep apnea, more than one-third $(37.7 \%)$ reported excessive sleepiness levels $(\mathrm{P}<0.0001)$, and $47.7 \%$ reported loud or very loud snoring $(\mathrm{P}<0.0001)$. There was no significant difference in the prevalence of excessive sleepiness between farm (16.2\%) and nonfarm (15.7\%) residents. Similar results were observed for the prevalence of self-reported 'doctor-diagnosed' sleep apnea between farm (6.0\%) and nonfarm $(6.1 \%)$ residents.

Univariate binary logistic regression analysis showed that overweight (BMI $25 \mathrm{~kg} / \mathrm{m}^{2}$ to $30 \mathrm{~kg} / \mathrm{m}^{2}$ ) and obese $\left(\mathrm{BMI}>30 \mathrm{~kg} / \mathrm{m}^{2}\right.$ ), male sex, older age, lower education level, married/common law marital status, lower income status, loud snoring and shortness of breath were associated with a risk of having a higher ESS score (Table 1). Also, 'doctor-diagnosed' cardiopulmonary morbidities (heart disease, heart attack, hardening of arteries, high blood pressure, tuberculosis, stroke, attack of bronchitis, diabetes, sinus troubles, chronic bronchitis and chronic obstructive pulmonary disease) were associated with a risk of having a higher ESS score (Table 2).

As shown in Table 2, multivariate binary logistic regression analysis indicated that the risk of having a higher ESS score increased with age (for $>65$ years of age, OR 1.46 [95\% CI 1.19 to 1.79$]$ ); for 56 to 65 years of age (OR 1.49 [95\% CI 1.22 to 1.83]), male sex (OR 2.02 [95\% CI 1.76 to 2.33 ), obesity (BMI $>30 \mathrm{~kg} / \mathrm{m}^{2}$ ) (OR 1.34 [95\% CI 1.11 to 1.62), 'not enough money left over at the end of the month' as an indicator of lower socioeconomic status (OR 1.30 [95\% CI 1.09 to 1.56), married or living with partner (OR 1.48 [95\% CI 1.21 to 1.81]), loud or very loud snoring (OR 1.64 [95\% CI 1.41 to 1.91) and 'doctordiagnosed sinus trouble' (OR 1.31 [95\% CI 1.14 to 1.51]). Smoking status was neither a confounder nor an effect modifier.

\section{DISCUSSION}

Consistent with results from our pilot study (40), the present study highlights that a significant percentage of the rural population experienced symptoms of excessive daytime sleepiness. This finding has implications for potential increased risks for farm-related and other forms of accidents/injuries, as well as potential increased cardiovascular morbidity risk.

The prevalence rates of excessive daytime sleepiness significantly depend on the definition used. Previous studies have reported prevalence rates of $5 \%$ to $23 \%$ in adult populations $(1-10)$. These studies have been summarized in Table 3. Our results using a definition of ESS score $>10$ for excessive sleepiness showed an overall prevalence of $15.9 \%$. Thus, our data, in the total population studied with the overall excessive daytime sleepiness defined as an ESS score $>10$, are consistent with other epidemiological studies. However, our finding that $21 \%$ of men reported ESS scores $>10$ places our results at the upper range.

The conventional threshold ESS score is $>10$. However, it should be acknowledged that Aurora et al (49) recently reported a clear association between ESS score and average sleep latency as objectively 
TABLE 2

Multivariable logistic regression of the prevalence of Epworth Sleepiness Scale score

\begin{tabular}{|c|c|}
\hline Variable & Multivariable OR $(95 \% \mathrm{Cl})$ \\
\hline \multicolumn{2}{|l|}{ Sex } \\
\hline Male & $1.93(1.67-2.23)$ \\
\hline Female (reference) & 1.00 \\
\hline \multicolumn{2}{|l|}{ Age group, years } \\
\hline$>65$ & $1.41(1.14-1.74)$ \\
\hline $56-65$ & $1.42(1.15-1.76)$ \\
\hline $46-55$ & $1.03(0.84-1.28)$ \\
\hline 18-45 (reference) & 1.00 \\
\hline \multicolumn{2}{|l|}{ Body mass index, $\mathrm{kg} / \mathrm{m}^{2}$} \\
\hline Obese $(>30)$ & $1.24(1.02-1.51)$ \\
\hline Overweight (25-30) & $1.05(0.87-1.26)$ \\
\hline Normal $(<25)$ (reference) & 1.00 \\
\hline \multicolumn{2}{|l|}{ Money left over at end of the month } \\
\hline Not enough & $1.30(1.09-1.57)$ \\
\hline Just enough & $0.98(0.80-1.16)$ \\
\hline Some (reference) & 1.00 \\
\hline \multicolumn{2}{|l|}{ Smoking status } \\
\hline Current smoker & $0.83(0.66-1.05)$ \\
\hline Ex-smoker & $0.97(0.83-1.14)$ \\
\hline Never smoker (reference) & 1.00 \\
\hline \multicolumn{2}{|l|}{ Marital status } \\
\hline Married/common law/living together & $1.26(1.01-1.57)$ \\
\hline Widowed/divorced/separated/single (reference) & 1.00 \\
\hline \multicolumn{2}{|l|}{ Loud snoring } \\
\hline Loud or very loud & $1.82(1.51-2.20)$ \\
\hline No or slightly (reference) & 1.00 \\
\hline \multicolumn{2}{|l|}{ Doctor ever diagnosed sinus trouble } \\
\hline Yes & $1.30(1.12-1.51)$ \\
\hline No (reference) & 1.00 \\
\hline \multicolumn{2}{|l|}{ Location of residence } \\
\hline Farm & $0.95(0.82-1.10)$ \\
\hline Nonfarm (reference) & 1.00 \\
\hline \multicolumn{2}{|l|}{ Region of province } \\
\hline North (west and east) & $1.06(0.91-1.23)$ \\
\hline South (west and east) (reference) & 1.00 \\
\hline
\end{tabular}

measured from multiple sleep latency testing and identified an ESS score $>13$ as most effectively predicting objective sleepiness in their study population.

Factors associated with excessive daytime sleepiness in the present study included age, male sex, obesity (BMI $>30 \mathrm{~kg} / \mathrm{m}^{2}$ ), lower socioeconomic status, married or living with partner, loud snoring and 'doctor-diagnosed sinus trouble'. Increasing age, male sex and obesity are well recognized to be associated with increased risk for OSA $(16,24)$. Lower socioeconomic status has also been clearly linked with an increased likelihood of obesity (50). Increased neck circumference and BMI are particularly are strong predictors of OSA in men (51). Increased neck circumference, BMI and several other truncal measures have also been reported to be associated with elevated apneahypopnea indexes in a recent study involving women referred for polysomnography (52). However, sex differences in OSA-associated symptoms and body fat distribution have been reported, which could impact identification or suspicion of OSA in women in a general population (53). Snoring has been also well recognized as an upper airway sign of possible OSA, and is included in validated identification questionnaires such as the Berlin Questionnaire and the STOP. BANG instrument $(54,55)$. Nugent et al (6) reported that the strongest risk factor identified for excessive daytime sleepiness was a
TABLE 3

Prevalence rates of excessive daytime sleepiness

\begin{tabular}{|c|c|c|c|}
\hline OSA definition & $\begin{array}{l}\text { Location or study } \\
\text { population }\end{array}$ & Prevalence, \% & $\begin{array}{l}\text { Author } \\
\text { (reference), year }\end{array}$ \\
\hline ESS > 10 & Rural Saskatchewan & 15.9 & Current study \\
\hline $\begin{array}{l}\text { EDS of } 3-4 \text { on a } \\
\text { subjective } 4 \text {-point } \\
\text { scale }\end{array}$ & Northern Ireland & 19.8 & $\begin{array}{l}\text { Nugent et al (6), } \\
2001\end{array}$ \\
\hline$E S S>10$ & Korea & 12.2 & $\begin{array}{l}\text { Joo et al (5), } \\
2009\end{array}$ \\
\hline $\begin{array}{l}\text { ESS index } \\
\text { correlation }\end{array}$ & Multiethnic Asian & 9 & $\begin{array}{l}\mathrm{Ng} \text { and } \operatorname{Tan}(10), \\
2005\end{array}$ \\
\hline $\begin{array}{l}\text { EDS of } 4-5 \text { on a } \\
\text { subjective } 5 \text {-point } \\
\text { scale }\end{array}$ & Japan, adults & 15 & Liu et al (3), 2000 \\
\hline$E S S>10$ & Australia & $8.5-12$ & $\begin{array}{l}\text { John and Hocking } \\
\text { (9), } 1997\end{array}$ \\
\hline $\begin{array}{l}\text { Presence of } \\
\text { sleepiness, } \\
\text { 3x/week, } \\
\text { impairing daytime } \\
\text { activities }\end{array}$ & Brazil & 16.8 & $\begin{array}{l}\text { Hara et al (8), } \\
2004\end{array}$ \\
\hline$E S S>10$ & $\begin{array}{l}\text { Australia, age } \\
55-85 \text { years }\end{array}$ & 15.3 & $\begin{array}{l}\text { Vashum et al (7), } \\
2013\end{array}$ \\
\hline
\end{tabular}

EDS Excessive daytime somnolescence; ESS Espworth Sleepiness Scale score; OSA Obstructive sleep apnea

history of loud snoring (OR 2.62). We additionally observed 'sinus trouble' to be independently associated with excessive daytime sleepiness in our study population. This is consistent with previous reports linking OSA and sinus dysfunction $(56,57)$.

A Greek study (19) reported increased risk of OSA in married subjects compared with individuals who were single. We observed similar results for excessive daytime sleepiness. Conversely, Teculescu et al (20) reported the prevalence of sleep-disordered symptoms were not significantly different between groups based on marital status in a French population. Our results also indicated that socioeconomic status using 'money left at end of the month' as an indicator was significantly associated with excessive daytime sleepiness. Other studies have demonstrated that socioeconomic status, as measured by education, occupation and income, was associated with excessive sleepiness $(6,19,25,58)$

Associations between smoking and OSA have been reported $(56,59)$, as have alcohol use and OSA (60-62). In the present study, we did not observe associations between these factors and excessive daytime sleepiness. In addition, there have been some reports of depressive symptomatology associated with excessive daytime sleepiness (63). Because we did not include questionnaire assessments of mental health or depression in our survey instrument, we are unable to address the contribution of this possible risk factor.

We did not observe any association between location of residence (farm or nonfarm) or farming as the current occupation and excessive daytime sleepiness. In addition, there was a considerable north-south distance between the study quadrants (from the 49th to the 53rd parallels). One may speculate that this could lead to a small difference (approximately $40 \mathrm{~min}$ ) in total daylight time, which could affect sleep patterns (64). However, analysis of the north to south cohorts did not show any significant difference for the prevalence of excessive daytime sleepiness.

Overall, we observed that the risk factors identified with excessive daytime sleepiness in our population were generally recognized as also associated with OSA in other populations. It is likely that this high prevalence of elevated ESS scores is a signal for elevated prevalence of OSA in our rural population. Although an elevated ESS score may lend weight to a suspicion of OSA, it should be acknowledged that 
there is some controversy with regard to ESS accuracy. The association between subjective and objective sleepiness is not fully understood and the ESS scores should be interpreted with clinical correlation $(49,65)$. In addition, there is only a limited relationship between the ESS and other sleep instruments, likely due to the questionnaires measuring different aspects of sleep (66). It is notable that although $70 \%$ of respondents in the present study reported 'snoring', only $21 \%$ of the men and $15.9 \%$ of total population had elevated ESS scores. This raises the concern that the prevalence of OSA may be substantially higher than the prevalence of reported excessive daytime sleepiness in this rural population. Particularly, in light of associated cardiovascular morbidity and increased risk of injury/accident linked to undiagnosed and untreated OSA, these findings highlight the need for further assessment of OSA prevalence in rural populations.
Although overnight polysomnography is the gold standard for diagnosis, timely access may be an issue particularly for rural populations. Identification questionnaires for OSA and home-based diagnostic testing $(67,68)$ may be used for further evaluation in these populations. Increased OSA recognition, diagnosis and intervention may provide significant health care benefits to this population.

FUNDING: Funding was received from Canadian Institutes of Health Research "Saskatchewan Rural Health Study", Canadian Institutes of Health Research MOP-187209-POP-CCAA-11829.

DISCLOSURES: The authors have no financial disclosures of conflicts of interest to declare.

\section{APPENDIX}

The Saskatchewan Rural Health Study Team consists of James A Dosman MD, Punam Pahwa PhD and John Gordon PhD (Co-pricipal investigators) Donna Rennie PhD, Josh Lawson PhD, Bonnie Jansen PhD, Shelley Kirychuk PhD, Ambikaipakan Senthilselvan PhD, William Pickett PhD, Roger Pitblado PhD, Roland Dyck MD, Niels Koehncke MD, Yue Chen PhD, Chandima Karunanayake PhD and Louise Hagel MSc.

\section{REFERENCES}

1. Theorell-Haglöw J, Lindberg E, Janson C. What are the important risk factors for daytime sleepiness and fatigue in women? Sleep 2006;29:751-7.

2. Ohayon MM, Caulet M, Philip P, Guilleminault C, Priest RG. How sleep and mental disorders are related to complaints of daytime sleepiness. Arch Intern Med 1997;157:2645-52.

3. Liu X, Uchiyama M, Kim K, et al. Sleep loss and daytime sleepiness in the general adult population of Japan. Psychiatry Res 2000;93:1-11.

4. Johansson P, Brostrom A, Alehagen U, Svanborg E, Dahlstrom U. Sleep disturbances, daytime sleepiness and depressive symptomatology in elderly. The Corokind study. J Sleep Res 2006;15(Suppl 1):114.

5. Joo S, Baik I, Yi H, Jung K, Kim J, Shin C. Prevalence of excessive daytime sleepiness and associated factors in the adult population of Korea. Sleep Med 2009;10:182-8.

6. Nugent AM, Gleadhill I, Mccrum E, Patterson CC, Evans A, Macmahon J. Sleep complaints and risk factors for excessive daytime sleepiness in adult males in Northern Ireland. J Sleep Res 2001;10:69-74.

7. Vashum KP, McEvoy MA, Hancock SJ, et al. Prevalence and associations with excessive daytime sleepiness in an Australian older population. Asia Pac J Public Health 2013, October 4 (Epub ahead of print). DOI: 10.1177/1010539513497783

8. Hara C, Rocha FL, Lima-Costa MF. Prevalence of excessive daytime sleepiness and associated factors in a Brazilian community: The Bambui Study. Sleep Med 2004;5:31-6.

9. John M, Hocking B. Daytime sleepiness and sleep habits of Australian workers. Sleep 1997;20:844-9.

10. Ng TP, Tan WC. Prevalence and determinants of excessive daytime sleepiness in an Asian multiethnic population. Sleep Med 2005;6:523-9.

11. Leger D, Bayon V, Laaban JP, Philip P. Impact of sleep apnea on economics. Sleep Med Rev 2012;16:455-62.

12. Bailes S, Baltzan M, Rizzo D, et al. Sleep disorder symptoms are common and unspoken in Canadian general practice. Fam Pract 2009;26:294-300.

13. Mulgrew AT, Nasvadi G, Butt A, et al. Risk and severity of motor vehicle crashes in patients with obstructive sleep apnea/hypopnea. Thorax 2008;63:536-41.

14. Ulfberg J, Carter N, Edling C. Sleep-disordered breathing and occupational accidents. Scand J Work Environ Health 2000;26;237-42.

15. Phillips B, Cook Y, Schmitt F, Berry D. Sleep apnea: Prevalence of risk factors in a general population. South Med J 1989;82:1090-2.

16. Resta O, Caratozzolo G, Pannacciulli N, et al. Gender, age and menopause effects on the prevalence and the characteristics of obstructive sleep apnea in obesity. Eur J Clin Invest 2003;33:1084-9.

17. Mehra R, Stone KL, Blackwell T, et al. Prevalence and correlates of sleep-disordered breathing in older men: Osteoporotic fractures in men sleep study. J Am Geriatr Soc 2007;55:1356-64.
18. Larsson LG, Lindberg A, Franklin KA, Lundbäck B. Gender differences in symptoms related to sleep apnea in a general population and in relation to referral to sleep clinic. Chest 2003;124:204-11.

19. Charokopos N, Leotinidis M, Tsiamita M, Karkoulias K, Spiropoulos K. Sleep apnea syndrome in a referral population in Greece: Influence of social factors. Lung 2007:185:235-40.

20. Teculescu D, Hannhart B, Virian J-M, Montaut-Verient B, Michaely J-P. Marital status and sleep-disordered breathing in a sample of middle-aged French men. Lung 2004;182:355-62.

21. Kashyap R, Hock LM, Bowman TJ. Higher prevalence of smoking in patients diagnosed as having obstructive sleep apnea. Sleep Breath 2001;5:167-72.

22. Ekici M, Ekici A, Keles H, et al. Risk factors and correlates of snoring and observed apnea. Sleep Med 2008;9:290-6.

23. Goodfriend TL. Obesity, sleep apnea, aldosterone, and hypertension. Curr Hypertension Rep 2008;10:222-6.

24. Browman CP, Sampson MG, Yolles SF, et al. Obstructive sleep apnea and body weight. Chest 1984;85:435-8.

25. Ramsey CD, Walld R, Forget E, Delaive K, Prior H, Kryger M. Socioeconomic status and obstructive sleep apnea. Am J Respir Crit Care Med 2009;179:A1255.

26. Taylor-Gjevre RM, Gjevre JA, Nair B, Skomro R, Lim HJ. Hypersomnolence and sleep disorders in a rheumatic disease patient population. J Clin Rheumatol 2010;16:255-61.

27. Taylor-Gjevre RM, Nair BV, Gjevre JA. Obstructive sleep apnoea in relation to rheumatic disease. Rheumatology (Oxford) 2013;52:15-21.

28. Heaton K, Azuero A, Reed D. Obstructive sleep apnea indicators and injury in older farmers. J Agromedicine 2010;15:148-56.

29. Dosman JA, Hagel L, Skomro R, Sun X, Day AG, Pickett W; for the Saskatchewan Farm Injury Team. Loud snoring is a risk factor for occupational injury in farmers. Can Respir J 2013;20:42-6.

30. Johns MW. A new method for measuring daytime sleepiness: The Epworth Sleepiness Scale. Sleep 1991;14:540-5.

31. Johns MW. Daytime sleepiness, snoring, and obstructive sleep apnea: The Epworth Sleepiness Scale. Chest 1993;103:30-6.

32. Johns MW, Hocking B. Excessive daytime sleepiness: Daytime sleepiness and sleep habits of Australian workers. Sleep 1997;20:844-9.

33. Pang KP, Terris DJ. Screening for obstructive sleep apnea: An evidence-based analysis. Am J Otolaryngol Head Neck Med Surg 2006;27:112-8.

34. Zou J, Guan J, Yi H, et al. An effective model for screening obstructive sleep apnea: A large-scale diagnostic study. PLoS One 2013;8:e80704.

35. Netzer NC, Stoohs RA, Netzer CM, Clark K, Strohl KP. Using the Berlin questionnaire to identify patients at risk for the sleep apnea syndrome. Ann Intern Med 1999;131:485-91.

36. Johns MW. Sensitivity and specificity of the multiple sleep latency test (MSLT), the maintenance of the wakefulness test and the 
Epworth Sleepiness Scale: Failure of the MSLT as a gold standard. J Sleep Res 2000;9:5-11.

37. Johns MW. Reliability and factor analysis of the Epworth Sleepiness Scale. Sleep 1992;15:376-81.

38. Smolley LA, Ivey C, Farkas M, Faucette E, Murphy S. Epworth Sleepiness Scale is useful for monitoring daytime sleepiness. J Sleep Res 1993;22:389.

39. Johns MW. Sleepiness in different situations measured by the Epworth Sleepiness Scale. Sleep 1994;17:703-10.

40. Pahwa P, Karunanayake CP, Hagel L, et al. Prevalence of high Epworth Sleepiness Scale in a rural population. Can Respir J 2012;19:e10-e14.

41. Pahwa P, Karunanayake CP, Hagel L, et al. The Saskatchewan Rural Health Study: An application of a population health framework to understand respiratory health outcomes. BMC Res Notes 2012, 5:400. <www.biomedcentral.com/1756-0500/5/400> (Accessed March 6, 2014).

42. Dillman DA. Mail and telephone surveys: The total design method. New York: Wiley, 1978.

43. Dillman DA. Mail and Internet Surveys: The tailored design method, 2nd edn. New York: Wiley \& Sons Inc, 2000.

44. Health Canada. 1994. Strategies for Population Health: Investing in the Health of Canadians. Cat. No. H39-316/1994E, Ottawa: Health Canada, Minister of Supply and Services Canada.

45. Pickett W, Day L, Hagel L, et al. The Saskatchewan Farm Injury Cohort: Rationale and methodology. Public Health Rep 2008;123:567-75.

46. Statistics Canada National Population Health Survey Household Component: Documentation for the Derived Variables and the Constant Longitudinal Variables. < www.statcan.gc.ca/imdb-bmdi/ document/3225_D10_T9_V3-eng.pdf> (Accessed November 15, 2012).

47. Pan W. Akaike's information criterion in generalized estimating equations. Biometrics 2001;57:120-5.

48. Hardin JW, Hilbe JM. Generalized Estimating Equations. New York: Chapman \& Hall/CRC, 2003.

49. Aurora RN, Caffo B, Crainiceanu C, Punjabi NM. Correlating subjective and objective sleepiness: Revisiting the association using survival analysis. Sleep 2011:334:1707-14.

50. McLaren L. Socioeconomic status and obesity. Epidemiol Rev 2007;29:29-48.

51. Hoffstein V, Szalai JP. Predictive value of clinical features in diagnosing obstructive sleep apnea. Sleep 1993;16:118-22.

52. Gjevre JA, Taylor-Gjevre RM, Reid JK, Skomro R, Cotton D. Inter-observer reliability of candidate predictive morphometric measurements for women with suspected obstructive sleep apnea. J Clin Sleep Med 2013:9:695-9.

53. Whittle AT, Marshall I, Mortimore IL, Wraith PK, Sellar RJ, Douglas NJ. Neck soft tissue and fat distribution: Comparison between normal men and women by magnetic resonance imaging. Thorax 1999;54:323-8.

54. Netzer NC, Stoohs RA, Netzer CM, Clark K, Strohl KP. Using the Berlin questionnaire to identify patients at risk for the sleep apnea syndrome. Ann Intern Med 1999;131:485-91.

55. Chung F, Elsaid H. Screening for obstructive sleep apnea before surgery: Why is it important? Curr Opin Anaesthesiol 2009;22:405-11.

56. Young T, Peppard PE, Gottlieb DJ. Epidemiology of obstructive sleep apnea: A population Health Perspective. Am J Respir Crit Care Med 2002;165:1217-39.

57. Zhang XL, Wanh H, Li C. Association between severe obstructive sleep apnea syndrome and sinus dysfunction. European Respiratory Society Annual Congress 2007; Eposter:E3054; page 508S. <www.ersnet.org/learning_resources_player/abstract_print_07/ files/312.pdf> (Accessed March 6, 2014).

58. Li X, Sundquist K, Sundquist J. Socioeconomic status and occupation as risk factors for obstructive sleep apnea in Sweden: A population-based study. Sleep Med 2008;9:129-36.

59. Al Lawati NM, Patel SR, Ayas NT. Epidemiology, risk factors, and consequences of obstructive sleep apnea and short sleep duration. Prog Cardiovasc Dis 2009;51:285-93.

60. Issa FG, Sullivan CE. Alcohol, snoring and sleep apnea. J Neurol Neurosurg Psychiatry 1982;45:353-9.

61. Peppard PE, Austin D, Brown RL. Association of alcohol consumption and sleep disordered breathing in men and women. J Clin Sleep Med 2007;3:265-70.

62. Tsutsumi W, Miyazaki S, Itasaka Y, Togawa K. Influence of alcohol on respiratory disturbance during sleep. Psychiatry Clin Neurosci 2000;54:332-3.

63. Dauvilliers Y, Lopez R, Ohayon M, Bayard S. Hypersomnia and depressive symptoms: Methodological and clinical aspects. BMC Med 2013;11:78.

64. Harrison Y. The impact of daylight saving time on sleep and related behaviours. Sleep Med Rev 2013;17:285-92.

65. Smith SS, Oei TP, Douglas JA, et al. Confirmatory factor analysis of the Epworth Sleepiness Scale (ESS) in patients with obstructive sleep apnoea. Sleep Med 2008;9:739-44.

66. Mondal P, Gjevre JA, Taylor-Gjevre RM, Lim HJ. Relationship between the Pittsburgh sleep quality index and the Epworth Sleepiness Scale in a sleep laboratory referral population. Nat Sci Sleep 2013;5:15-21.

67. Gjevre JA, Taylor-Gjevre RM, Skomro R, et al. Comparison of polysomnographic and portable home monitoring assessments of obstructive sleep apnea in Saskatchewan women. Can Respir J 2011;18:271-4.

68. Ryan F. Ambulatory monitoring for obstructive sleep apnea: It's not the device that matters, but how the data are used. Can Respir J 2011;18:318-9. 


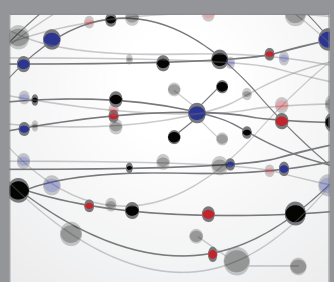

The Scientific World Journal
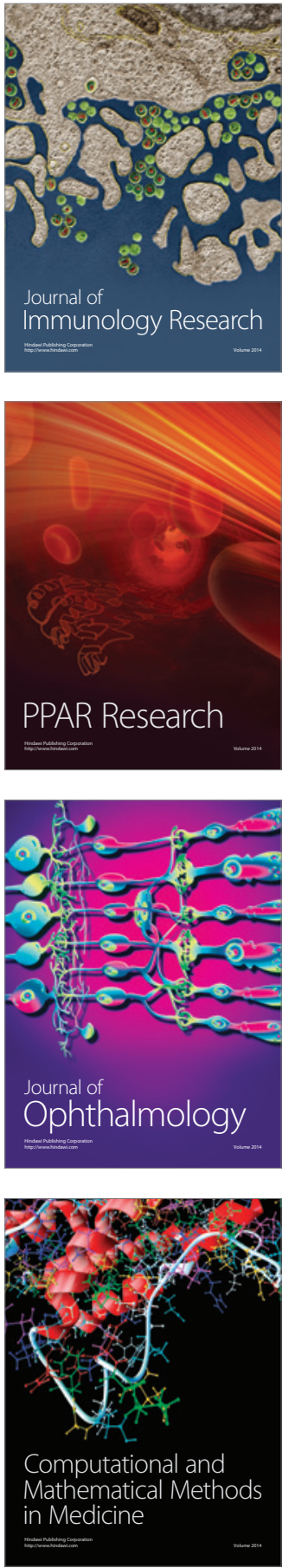

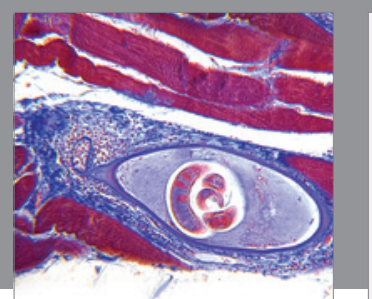

Gastroenterology Research and Practice

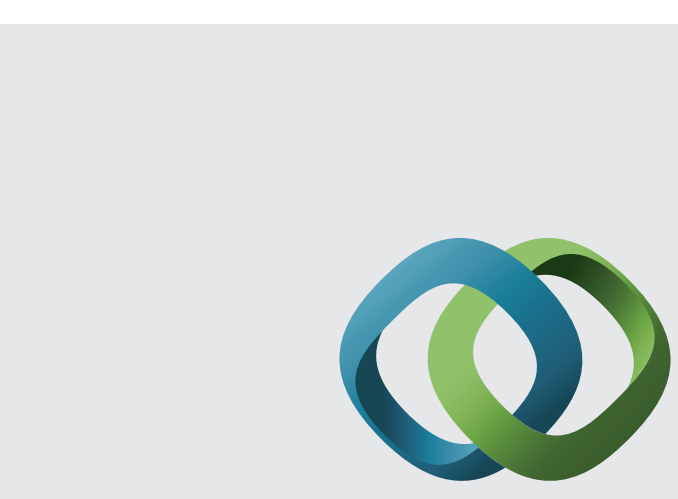

\section{Hindawi}

Submit your manuscripts at

http://www.hindawi.com
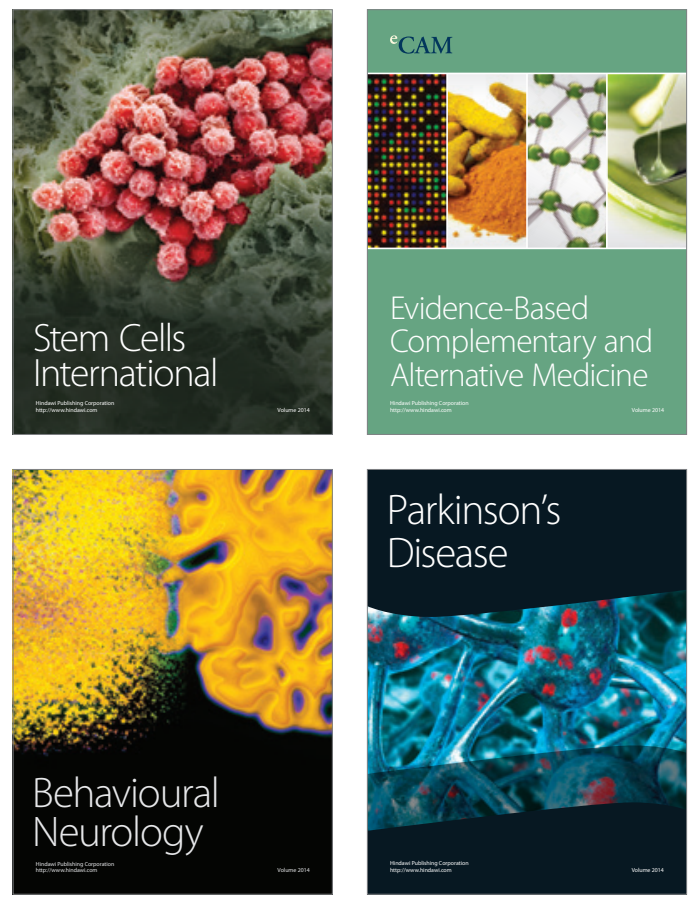
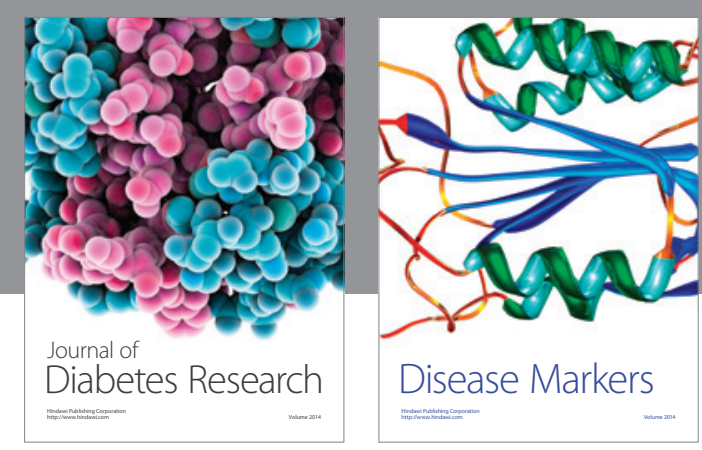

Disease Markers
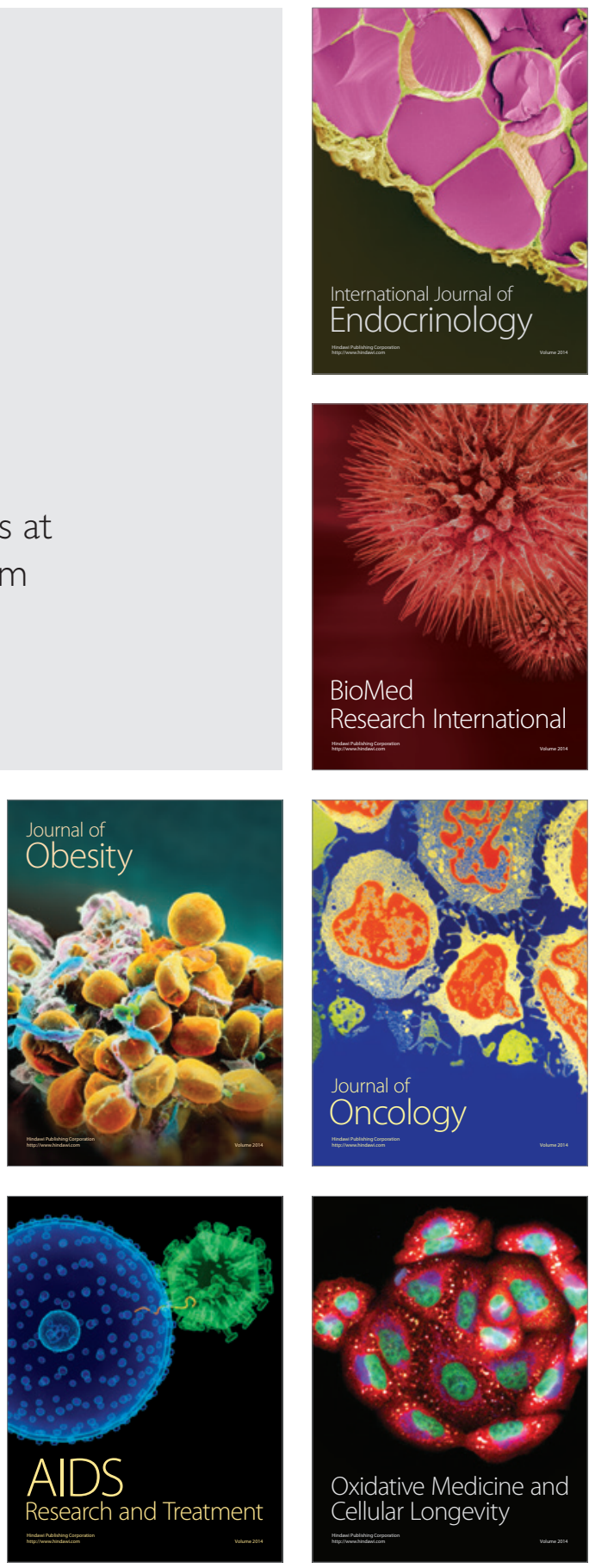